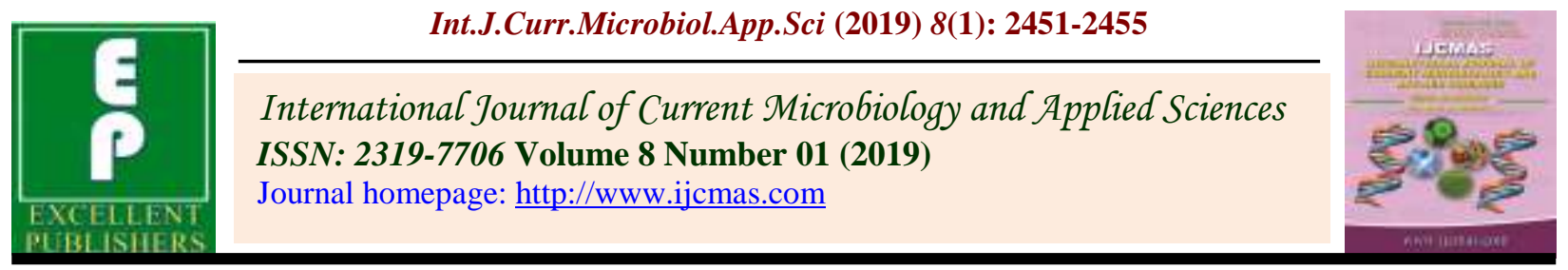

Original Research Article

https://doi.org/10.20546/ijcmas.2019.801.258

\title{
Comparative Performance of Oriental Hybrid Lily cv. White Cup under Protected Conditions
}

\author{
Sunita Kumari*, Santosh Kumar and C.P. Singh \\ Department of Horticulture, G. B. Pant University of Agriculture and Technology, Pantnagar \\ (U. S. Nagar) Uttarakhand, India \\ *Corresponding author
}

\section{A B S T R A C T}

\section{Keywords}

Oriental Hybrid

Lily cv. White Cup

Article Info

Accepted:

17 December 2018

Available Online:

10 January 2019
The present investigation was conducted at Model Floriculture Center of G. B. Pant University of Agriculture and Technology, Pantnagar during the year 2016-17 and 201718. The experiment was laid out in complete randomized design with two treatments and fifteen replications under polyhouse and shade net conditions. Most of the vegetative characters like plant height, total number of leaves, length and width of leaves, stem diameter, average plant diameter, plant spreading, leaf area per plant, leaf area index were found superior under shade net conditions but the flower quality characters like time required to bud initiation, number of bud per plant and vase life was found superior under polyhouse conditions as compared to shade net house conditions.

\section{Introduction}

The lily is most important bulbous cut flower. In northern and western Himalayan region found more than 100 species are found but Asiatic, eastern and Oriental hybrid lily grown at commercial level for cut flower production. The oriental hybrid lily belongs to family Liliaceae and native to Japan and derived from $L$. auratum, $L$. speciosum, $L$. japonicum and L. rubellum. Oriental lilies have large beautiful white, pink, and cream colours flowers with pleasant aroma (Grassotti and Gimelli, 2011). The oriental hybrid lilies are mainly grown in temperate and moist region in the world including India. The oriental lily is cultivated in Netherlands, Israel, U.S.A., South Africa, Japan, Chile,
Italy, New Zealand and Mexico in the world. In India, Himachal Pradesh, Jammu and Kashmir and Upper Himalayan region of Uttarakhand lilies are grown in open field conditions. In plain region of India, lilies are grown in Maharashtra, West Bengal, Odisha, Karnataka, Uttar Pradesh, Haryana and Punjab under protected conditions. There is need to standardize protected condition for flowers quality production of oriental lily according to standards of national and international markets.

\section{Materials and Methods}

The present experiment was conducted at Model Floriculture Centre, G. B. Pant University of Agriculture and Technology, 
Pantnagar (U. S. Nagar) Uttarakhand during 2016-17 and 2017-18. The experiment was laid out in complete randomized design with two treatments i.e. polyhouse and shade net house conditions with fifteen replications. One replication had eight plants inside polyhouse as well as in shade net house conditions.

The planting of bulbs was done on raise bed $(15 \mathrm{~cm})$ and $30 \times 30 \mathrm{~cm}$ spacing. Before planting, the bulbs were treated with Bavistin WP @ $2 \mathrm{~g} /$ litre water and planting was done at last week of October. The crop was cultivated with standard cultural operation in both protected conditions. Five plants were selected for observations per replication per treatment.

The observations like time taken for bulb sprouting, plant height $(\mathrm{cm})$, number of leaves per plant, average length and width of leaves, average diameter of plant $(\mathrm{cm})$, plant spreading $(\mathrm{cm})$, leaf area $\left(\mathrm{cm}^{2}\right)$, leaf area index, stem diameter $(\mathrm{mm})$, time required for bud initiation (days), number of buds per plant, vase life of spikes at room temperature were recorded during experimentation. All the data were analyzed statistically.

\section{Results and Discussion}

A perusal of results of two years (2016-17 and 2017-18) and mean data of this experiment are presented in table 1 and 2 . The vegetative characters like plant height, total number of leaves, average width and length of leaves, plant spreading, leaf area per plant and leaf area index were observed significantly superior in shade net house conditions as compared to polyhouse conditions. The flowering characters like days taken to bud initiation, number of bud per plant and vase life of spike were observed superior in polyhouse conditions as compared to shade net house conditions.

\section{Vegetative characters}

The minimum days to bulb sprouting were significantly decreased (14.73, 12.38 and 13.57 per cent) in polyhouse condition as compared to shade net house conditions during the 2016-17, 2017-18 as well as pooled data. The plant height $(\mathrm{cm})$ was increased 3.99, 1.87 and 2.93 per cent in shade net house condition over to polyhouse conditions during the both year as well as pooled data, respectively. When we compare the total number of leaves per plant which were increased 2.10, 5.60 and 3.82 per cent in shade net house conditions over the polyhouse conditions during both years as well as pooled data, respectively. The leaf length $(15.13,15.20$ and 15.22 per cent) and width $(26.19,25.12$ and 25.35 per cent) were more in shade net house conditions over the polyhouse during the 2016-17, 2017-18 as well as pooled data, respectively. The average diameter of plant was 3.32, 3.90 and 3.59 per cent higher in shade net house condition than polyhouse conditions during both years as well as pooled data, respectively. The plant spreading was also found 6.71, 7.90 and 7.34 per cent higher in shade net house conditions than polyhouse conditions during 2016-17, 2017-18 and pooled data, respectively.

The leaf area per plant $\left(\mathrm{cm}^{2}\right)$ was significantly 4.61, 7.56 and 6.06 per cent more in shade net house conditions than polyhouse conditions during 2016-17, 2017-18 and pooled data, respectively. Leaf area index were 11.76, 16.66 and 14.14 per cent higher in shade net house conditions than polyhouse condition during 2016-17, 2017-18 and pooled data, respectively. The stem diameter were significantly $7.44,8.51$ and 8.09 per cent increased in shade net house condition over than polyhouse conditions during both year as well as pooled data, respectively. This might be due to difference in environmental conditions like as temperature and light 
intensity in both protected conditions. In polyhouse conditions temperature $\left(2-4{ }^{0} \mathrm{C}\right)$ is more as compared to shade net house conditions. During winter season, the temperature gradually decreased $\left(2-6{ }^{0} \mathrm{C}\right)$ from October to February, which is favourable for vegetative growth of oriental lily under shade net house condition but in polyhouse conditions having $2-4{ }^{0} \mathrm{C}$ more temperature as compared to shade net house, which induced the early bud initiation due to decreased the length of plant with along with vegetative characters. The similar studies were conducted by Mohanty et al., (2011) on rose and they reported that better plant growth was found under 50 per cent shade net conditions. Singh and Kumar (2018) reported that better plant growth was found under shade net house conditions as compared to polyhouse condition. Kumar and Kumar (2001) recorded that maximum leaf area, maximum plant spreading and number of leaves of gerbera was found under 50 per cent shade net conditions. Fatmi et al., (2018) reported that plant growth of Asiatic hybrid lily cv. Pollyanna like plant height, leaf area, plant spread and stem length were found highest under shade net conditions.

Table.1 Effect of protected conditions on vegetative characters of oriental hybrid lily cv. White Cup

\begin{tabular}{|c|c|c|c|c|c|c|c|}
\hline Parameters & $\begin{array}{l}\text { Days to } \\
\text { bulb } \\
\text { sprouting }\end{array}$ & $\begin{array}{c}\text { Plant } \\
\text { height } \\
\text { (cm) }\end{array}$ & $\begin{array}{c}\text { Total } \\
\text { number } \\
\text { of leaves/ } \\
\text { plant }\end{array}$ & $\begin{array}{l}\text { Length of } \\
\text { leaves } \\
\text { (cm) }\end{array}$ & $\begin{array}{c}\text { Width of } \\
\text { leaves } \\
\text { (cm) }\end{array}$ & $\begin{array}{l}\text { Average } \\
\text { plant } \\
\text { diameter } \\
(\mathrm{cm})\end{array}$ & $\begin{array}{c}\text { Plant } \\
\text { spreading } \\
(\mathrm{cm})\end{array}$ \\
\hline Year & \multicolumn{7}{|c|}{ 2016-17 } \\
\hline Polyhouse & 7.67 & 88.02 & 44.16 & 11.43 & 2.10 & 30.66 & 738.30 \\
\hline $\begin{array}{c}\text { Shade net } \\
\text { house }\end{array}$ & 8.80 & 91.54 & 45.09 & 13.16 & 2.65 & 31.68 & 787.84 \\
\hline F test & $\mathrm{S}$ & $\mathrm{S}$ & $\mathrm{S}$ & $\mathrm{S}$ & $\mathrm{S}$ & $\mathrm{S}$ & $\mathrm{S}$ \\
\hline C.D. $(P=0.05)$ & 0.42 & 0.79 & 0.58 & 0.07 & 0.034 & 0.15 & 7.25 \\
\hline SE $(\mathbf{m}) \pm$ & 0.14 & 0.27 & 0.20 & 0.026 & 0.012 & 0.05 & 2.49 \\
\hline Year & \multicolumn{7}{|c|}{ 2017-18 } \\
\hline Polyhouse & 7.51 & 89.17 & 43.17 & 11.44 & 2.07 & 30.48 & 729.30 \\
\hline $\begin{array}{l}\text { Shade net } \\
\text { house }\end{array}$ & 8.44 & 90.84 & 45.59 & 13.18 & 2.59 & 31.67 & 787.51 \\
\hline F test & $\mathrm{S}$ & $\mathrm{S}$ & $\mathrm{S}$ & $\mathrm{S}$ & $\mathrm{S}$ & $\mathrm{S}$ & $\mathrm{S}$ \\
\hline C.D. $(P=0.05)$ & 0.44 & 1.21 & 1.04 & 0.058 & 0.028 & 0.075 & 3.60 \\
\hline \multirow[t]{2}{*}{ SE(m) \pm} & 0.15 & 0.41 & 0.35 & 0.020 & 0.010 & 0.026 & 1.23 \\
\hline & \multicolumn{7}{|c|}{ Pooled data } \\
\hline Polyhouse & 7.59 & 88.59 & 43.67 & 11.43 & 2.09 & 30.57 & 733.78 \\
\hline $\begin{array}{l}\text { Shade net } \\
\text { house }\end{array}$ & 8.62 & 91.19 & 45.34 & 13.17 & 2.62 & 31.67 & 787.67 \\
\hline F test & $\mathrm{S}$ & $\mathrm{S}$ & $\mathrm{S}$ & $\mathrm{S}$ & $\mathrm{S}$ & $\mathrm{S}$ & $\mathrm{S}$ \\
\hline C.D. $(P=0.05)$ & 0.34 & 0.78 & 0.70 & 0.050 & 0.024 & 0.096 & 4.58 \\
\hline $\mathrm{SE}(\mathbf{m}) \pm$ & 0.12 & 0.26 & 0.24 & 0.017 & 0.008 & 0.033 & 1.57 \\
\hline
\end{tabular}


Table.2 Effect of protected conditions on vegetative and flowering characters of oriental hybrid lily cv. White Cup

\begin{tabular}{|c|c|c|c|c|c|c|}
\hline Parameters & $\begin{array}{c}\text { Leaf } \\
\text { area/plant } \\
\left(\mathrm{cm}^{2}\right)\end{array}$ & $\begin{array}{l}\text { Leaf } \\
\text { area } \\
\text { index }\end{array}$ & $\begin{array}{c}\text { Stem } \\
\text { diameter } \\
(\mathbf{m m})\end{array}$ & $\begin{array}{c}\text { Time } \\
\text { required for } \\
\text { bud initiation } \\
\text { (days) }\end{array}$ & $\begin{array}{c}\text { Number } \\
\text { of buds } \\
\text { per plant }\end{array}$ & Vase life (days) \\
\hline Year & \multicolumn{6}{|c|}{ 2016-17 } \\
\hline Polyhouse & 809.66 & 1.02 & 8.86 & 58.53 & 6.69 & 16.11 \\
\hline $\begin{array}{c}\text { Shade net } \\
\text { house }\end{array}$ & 847.03 & 1.14 & 9.52 & 67.96 & 6.43 & 14.91 \\
\hline F test & $\mathrm{S}$ & $\mathrm{S}$ & $\mathrm{S}$ & $\mathrm{S}$ & $\mathrm{S}$ & $\mathrm{S}$ \\
\hline C.D. $(P=0.05)$ & 20.53 & 0.027 & 0.12 & 0.77 & 0.16 & 0.31 \\
\hline SE(m) \pm & 7.05 & 0.009 & 0.04 & 0.26 & 0.05 & 0.10 \\
\hline Year & \multicolumn{6}{|c|}{ 2017-18 } \\
\hline Polyhouse & 762.38 & 0.96 & 8.93 & 58.10 & 6.78 & 15.64 \\
\hline $\begin{array}{l}\text { Shade net } \\
\text { house }\end{array}$ & 820.04 & 1.12 & 9.69 & 66.71 & 6.52 & 14.72 \\
\hline F test & $\mathrm{S}$ & $\mathrm{S}$ & $\mathrm{S}$ & $\mathrm{S}$ & $\mathrm{S}$ & $\mathrm{S}$ \\
\hline C.D. $(P=0.05)$ & 25.06 & 0.032 & 0.08 & 0.62 & 0.16 & 0.39 \\
\hline SE(m) \pm & 8.60 & 0.011 & 0.02 & 0.21 & 0.05 & 0.13 \\
\hline & \multicolumn{6}{|c|}{ Pooled data } \\
\hline Polyhouse & 785.90 & 0.99 & 8.89 & 58.32 & 6.73 & 15.87 \\
\hline $\begin{array}{c}\text { Shade net } \\
\text { house }\end{array}$ & 833.58 & 1.13 & 9.61 & 67.33 & 6.47 & 14.82 \\
\hline F test & $\mathrm{S}$ & $\mathrm{S}$ & $\mathrm{S}$ & $\mathrm{S}$ & $\mathrm{S}$ & $\mathrm{S}$ \\
\hline C.D. $(P=0.05)$ & 19.38 & 0.023 & 0.06 & 0.45 & 0.12 & 0.28 \\
\hline SE(m) \pm & 6.65 & 0008 & 0.02 & 0.15 & 0.04 & 0.09 \\
\hline
\end{tabular}

Flowering characters

Significantly lesser days $7.44,8.51$ and 8.09 per cent required for bud initiation under polyhouse conditions than shade net house conditions during both years as well as pooled data, respectively. The percentage of number of bud 4.04, 3.98 and 4.01 per cent were higher in polyhouse conditions over shade net house conditions during the year 2016-17, 2017-18 and pooled data, respectively. The vase life was significantly $8.04,6.25$ and 7.08 per cent higher in polyhouse conditions than shade net house conditions during the both years as well as pooled data, respectively.
This may be due to more light intensity and temperature $\left(2-4{ }^{0} \mathrm{C}\right)$ under polyhouse conditions which enhance the metabolic activities and affect the quality of flowers. The similar results were found by Gantait and Pal (2011) on spray chrysanthemum and reported that better quality of flower was found under polyhouse conditions. Teifel et al., (2007) also supported our findings through a study on carnation and reported that the best quality of flowers was produced under fan pad polyhouse as compared to shade net house. Mohanty et al., (2011) also reported that polyhouse conditions is improved the flower quality of rose under polyhouse condition as compared to shade net 
house condition. Barik (2013) found that polyhouse condition improved flower quality like early bud initiation, length and width of flower bud as well as flowers of Asiatic hybrid lily. Fatmi et al., (2018) reported that floral parameters like early bud emergence and early flower, number of buds and vase life were found better under polyhouse condition as compared to shade net house conditions

On the basis of these findings, it may be concluded that vegetative parameters were found superior under shade net conditions while, flower quality characters were found appreciable under polyhouse condition of oriental lily cv. White Cup. Therefore, considering the flower quality parameters of lily cultivation is recommended under polyhouse conditions.

\section{References}

Barik, D. (2013). Comparative performance of Asiatic Hybrid Lily (Lilium $s p$ ) varieties under open and protected environment. Master thesis, The Orissa University of Agriculture and Technology, Bhubhneswar.

Fatmi, U., Singh, D. and Bharti, S. (2018). Growth and flowering of Asiatic lily cv. Pollyanna as influenced by different growing environments. Plant Archives, 18(1): 760-762.
Gantait, S. S. and Pal, P. (2011). Comparative performance of spray chrysanthemum cultivars under polyhouse and openfield cultivation at different dates of planting. Journal of Horticultural Science, 6(2): 123-129.

Grassotti, A. and Gimelli, F. (2011). Bulb and cut flower production in the genus Lilium: current status and the future. In II International Symposium on the Genus Lilium 900 (pp. 21-35).

Kumar, D. and Kumar, R. (2001). Effect of modified environments on gerbera. Journal of Ornamental Horticulture, 4(1): 33-35.

Mohanty, C. R., Mohanty, A., Das, A. B. and Kar, D. S. (2011). Comparative performance of some rose varieties under open and protected environment. Asian Journal of Horticulture, 6(2): 288-293.

Singh, S. and Kumar, S. (2018). Comparative performance of gladiolus cv. Forta Rosa under different environmental conditions on growth and flowering. International Journal of Chemical Studies, 6(2): 2484-2488.

Teifel, M., Barvak, M., Ben Yaakou, E., Gatken, J., Tanny, J. and Cohen, S. (2007). Comparing greenhouse natural ventilation to fan and pad cooling. Acta Horticulturae, 761: 33-39.

\section{How to cite this article:}

Sunita Kumari, Santosh Kumar and Singh, C.P. 2019. Comparative Performance of Oriental Hybrid Lily cv. White Cup under Protected Conditions. Int.J.Curr.Microbiol.App.Sci. 8(01): 2451-2455. doi: https://doi.org/10.20546/ijcmas.2019.801.258 